UDC 004.932:004.942

\title{
Using multichannel satellite images for predictive modelling the «bloom» phytoplankton processes in shallow waters on supercomputer*
}

\author{
A.I. Sukhinov, A.V. Nikitina, A.E. Chistyakov** \\ Don State Technical University, Rostov-on-Don, Russian Federation \\ Southern Federal University, Rostov-on-Don, Russia
}

The paper covers the development and research of mathematical models of «bloom» phytoplankton processes, that cause hypoxic phenomena in shallow waters, on the basis of modern information technologies and computational methods. Expedition data and multichannel satellite images of remote sensing obtained by the SRC «Planet» are used for calibration and verification of the developed model. The methods of domain decomposition was used in a parallel implementation for computationally labours problems, taking into account the architecture and parameters of multiprocessor computer system.

Keywords: mathematical model, the «bloom» of phytoplankton, hypoxic phenomena, multichannel satellite images, supercomputer, parallel algorithms.

Introduction. Shallow water reservoirs experience a great anthropogenic load, with the runoff of rivers they receive biogenic substances that cause a surge of algae growth - «bloom». The phenomenon of fish freezing occurs periodically in shallow water in summer, because in them, because of high temperatures, there is a significant decrease in the content of dissolved oxygen consumed by organic decomposition $[1,2]$.

For the reconstruction of the «bloom» process, which caused the fish to snake in the South-East of the Sea of Azov in July 2013, a spatially inhomogeneous mathematical 3D model was developed. The results of satellite Earth monitoring obtained by SRC «Planet» are used in the work to monitor the quality of process modeling [3].

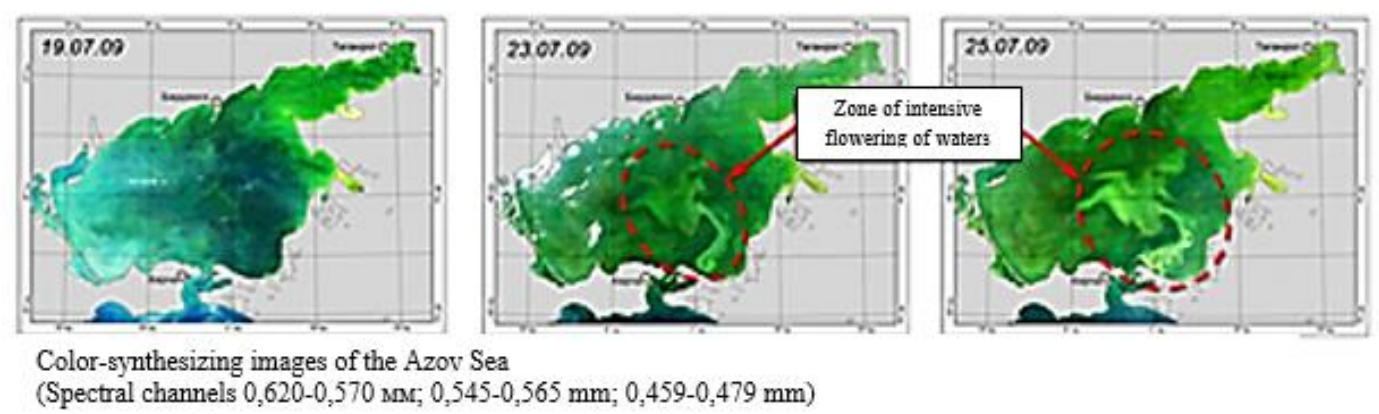

Fig. 1. Extensive zones of «bloom» in the Azov Sea

\footnotetext{
* The research is done with the financial support from RSF, Project No. 17-11-01286.

**E-mail: sukhinov@gmail.com, nikitina.vm@gmail.com, cheese_05@mail.ru
} 
Analysis of multichannel satellite images makes it possible to identify areas of the reservoir that are most prone to overseas phenomena.

In Fig. 2, it is possible to trace the dynamics of the development of the phenomenon of «bloom» that caused the fish to swim in the southeastern sector of the Sea of Azov on July 16, 2013. Fig. 2 shows the following notations: 1 - carrying out river or liminal waters from the sleeves and the delta of the river Kuban; 2 - zone of «bloom»; 3 - water of high degree of turbidity after wind wave destruction of the «bloom» zone.

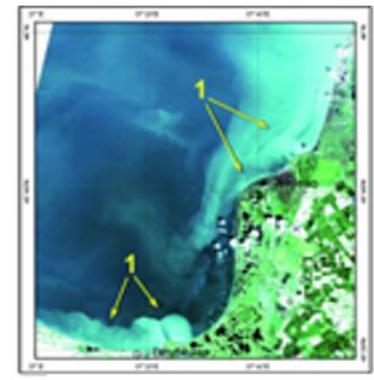

11.07.2013 08:15 UTC

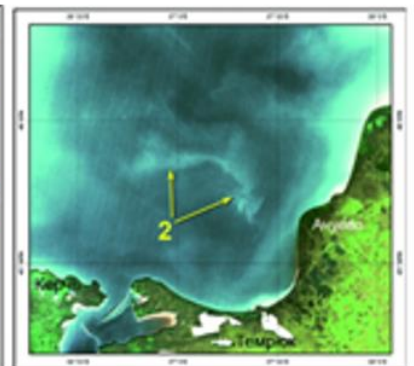

13.07.2013 06:55 UTC

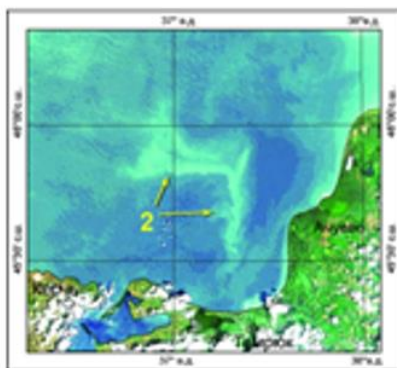

15.07.2013 08:50 UTC

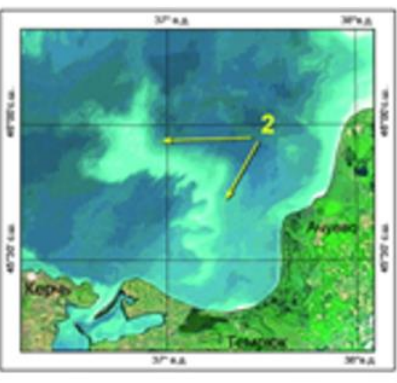

18.07.2013 11:05 UTC

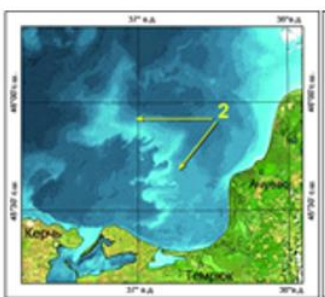

19.07.2013 08:30 UTC

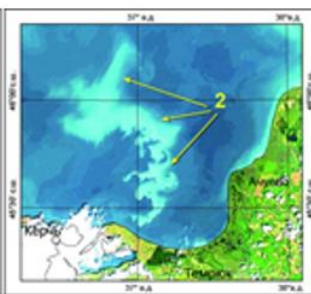

20.07.2013 10:53 UTC

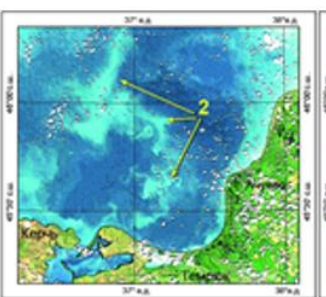

22.07.2013 10:40 UTC

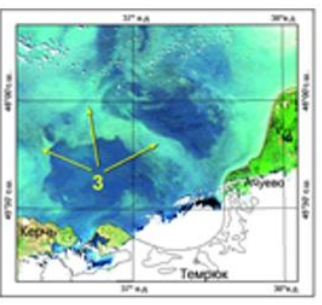

24.07.2013 10:28 UTC

Fig. 2. Dynamics of development of the process of «bloom» in the Azov Sea

The information about the wind speed and direction in Temryuk Bay in July 2016, provided by the weather station in Kerch (WMO_ID 33983) was used for it as input data (fig. 3).

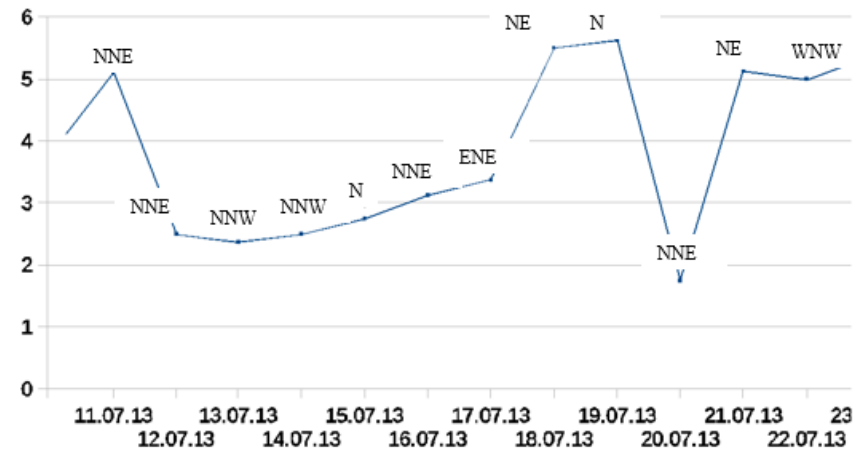

Fig. 3. The wind speed and direction in July 2013

Fig. 4 shows the data about the water temperature in the calculation area for the simulated time period. 


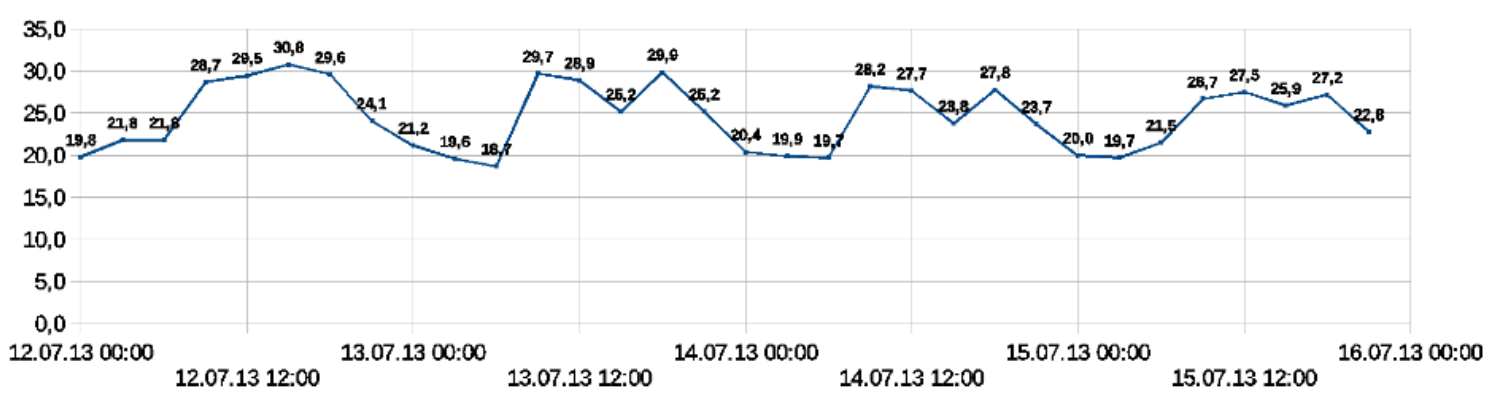

Fig. 4. Water temperature in July 2013

For the analysis of the state of the waters of the Azov Sea, the classes described by the Institute of Nature Protection and the Reserve Ministry of the Ministry of Ecology of Russia are presented in Table. 1, with the accepted designations: 1 - trophicity, quality class, character of saprobity, parameters; 2 - oligotrophy, very pure, xenosuperbility (I); 3 - mesotrophy, pure, beta-ligosa-trial (II); 4 - moderately polluted mesotrophy, alpha-oligosa-trial (III); 5 - eutrophy, contaminated, betamesos-test (IV); 6 - polytrophy, dirty, alpha-mesose-probing (V); 7 - hypereutrophy, very dirty, polysaprobism (VI); *) - flowing reservoirs; **) - inaccurate water bodies; ***) - Higher values are possible.

Table 1.

Parameters and alphabet of the classes of assessing the state of aquatic ecosystems.

\begin{tabular}{|c|c|c|c|c|c|c|}
\hline 1 & 2 & 3 & 4 & 5 & 6 & 7 \\
\hline $\begin{array}{l}\text { Transparency of water on the } \\
\text { Secchi disk, } \\
\mathrm{m}, *) \\
* *)\end{array}$ & $\begin{array}{l}3 \\
6 \\
\end{array}$ & $\begin{array}{c}0,7-3 \\
4 \\
\end{array}$ & $\begin{array}{c}0,5-0,7 \\
4\end{array}$ & $\begin{array}{c}0,3-0,5 \\
2\end{array}$ & $\begin{array}{c}0,1-0,3 \\
1\end{array}$ & $\begin{array}{c}0,05-0,1 \\
0,5\end{array}$ \\
\hline $\begin{array}{l}\text { Specific } \\
\text { electrical conductivity of water, } \\
\mu \mathrm{s} / \mathrm{cm} *) \\
* *)\end{array}$ & $\begin{array}{c}>400 \\
150\end{array}$ & $\begin{array}{l}700 \\
250\end{array}$ & $\begin{array}{c}700 \\
300 * * *\end{array}$ & $\begin{array}{c}1100 \\
500\end{array}$ & $\begin{array}{l}1300 \\
1000\end{array}$ & $\begin{array}{l}1600 \\
1000\end{array}$ \\
\hline $\begin{array}{l}\text { Index } \\
\text { saprobity } \\
\text { Phytoplankton by Watanabe }\end{array}$ & $85-100$ & $70-85$ & $50-70$ & $30-50$ & $15-30$ & $0-15$ \\
\hline $\begin{array}{l}\text { Concentration } \\
\mathrm{Cl} \ll \mathrm{a} », \mu \mathrm{g} / \mathrm{L}, * *)\end{array}$ & 3 & 8 & 8 & 15 & 30 & 60 \\
\hline $\begin{array}{l}\text { Biomass } \\
\text { phytoplankton, mg / } 1\end{array}$ & $0-0,1$ & $0,1-0,5$ & $0,5-1,0$ & $1,0-5,0$ & $5,0-50,0$ & $50-100$ \\
\hline $\begin{array}{l}\text { Gross daily production } \\
\text { of phytoplankton, } \mathrm{g} / \mathrm{m}^{2}\end{array}$ & $0-1,5$ & $1,5-3$ & $3-4,5$ & $4,5-7,5$ & $7,5-10,5$ & $10,5-12$ \\
\hline Shannon Index & $0-4$ & $1-4,5$ & $0-5$ & $0-5$ & $1,5-4,5$ & $0-4$ \\
\hline $\begin{array}{l}\text { Area of variation of } \mathrm{N} . \\
\mathrm{H} \text { min. - } \mathrm{N} \text { max. }\end{array}$ & $\begin{array}{c}0-1,5 \\
3-4\end{array}$ & $\begin{array}{c}1-2 \\
4-4,5 \\
\end{array}$ & $\begin{array}{c}0-2 \\
4,5-5 \\
\end{array}$ & $\begin{array}{c}0-2 \\
4,5-5 \\
\end{array}$ & $\begin{array}{l}1,5-2 \\
4-4,5 \\
\end{array}$ & $\begin{array}{c}0-1,5 \\
2-4\end{array}$ \\
\hline
\end{tabular}


1. Mathematical model of bloom processes in shallow water. The spatially inhomogeneous model of bloom of water is described by the equations:

$$
S_{i, t}^{\prime}+u \frac{\partial S_{i}}{\partial x}+v \frac{\partial S_{i}}{\partial y}+\left(w-w_{g i}\right) \frac{\partial S_{i}}{\partial x}=\mu_{i} \Delta S_{i}+\frac{\partial}{\partial z}\left(v_{i} \frac{\partial S_{i}}{\partial z}\right)+\psi_{i} .
$$

(1.1) - the equation for the change in the concentration of impurities, the index $i$ indicates the type of substance, $S_{i}$ - the concentration of the i-th impurity, $i=\overline{1,6} ; 1$ - total organic nitrogen $(N) ; 2-$ phosphates $\left(\mathrm{PO}_{4}\right) ; 3$ - phytoplankton; 4 - zooplankton; 5 - dissolved oxygen $\left(\mathrm{O}_{2}\right) ; 6$ - hydrogen sulphide ${ }^{\left(\mathrm{H}_{2} \mathrm{~S}\right)} ; u, v, w$ - components of the velocity vector of the water flow; $\psi_{i}-$ a chemicalbiological source (sink) or a term describing aggregation (clumping-splitting), if the corresponding component is a suspension.

Let us describe the design area of which is shown in fig. 5, which is a closed region bounded by the unperturbed surface of the reservoir $\Sigma_{0}$, the bottom $\Sigma_{H}=\Sigma_{H}(x, y)$ and the cylindrical surface $\sigma$ for $0<t \leq T_{0} . \quad \sum=\sum_{0} \cup \sum_{H} \cup \sigma-$ a piecewise smooth boundary of the region $G$ [4-7].

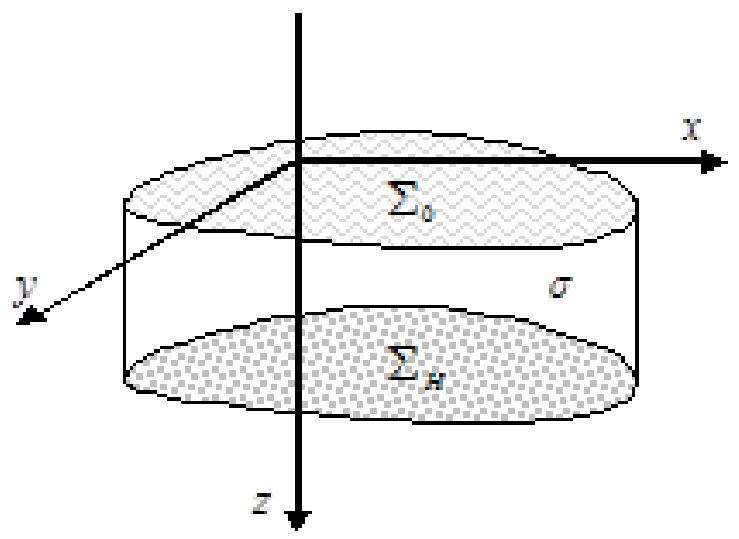

Fig. 5. The scheme of the computational domain $\bar{G}$

The system (1.1) is considered under the following boundary conditions:

$$
\begin{aligned}
& S_{i}=0 \text { on } \sigma, \text { if } U_{n}<0 ; \frac{\partial S_{i}}{\partial n}=0 \text { on } \sigma, \text { if } U_{n} \geq 0 ; \\
& S_{i, z}^{\prime}=\varphi\left(S_{i}\right) \text { on } \Sigma_{0} ; S_{i, z}^{\prime}=-\varepsilon_{i} S_{i} \text { on } \Sigma_{H},
\end{aligned}
$$

Where $\varepsilon_{i}$ - the absorption coefficient of the i-th component by the bottom material.

It is also necessary to add the initial conditions:

$$
\left.S_{i}\right|_{t=0}=S_{i 0}(x, y, z), i=\overline{1,6}
$$

The fields of water flow velocities calculated from the model [8-10] are used as input data for model (1.1)-(1.3). The discretization of the model (1.1)-(1.3) was carried out on the basis of schemes of an increased order of accuracy described in [11-14]. 
2. Numerical realization of the model of «bloom» of phytoplankton. To solve the grid problems that arise when the model problem (1.1)-(1.3) is discretized, a modified alternatingtriangular method (MATM) was used [15-17].

We describe the parallel algorithms used to solve problem (1.1)-(1.3), using different types of decomposition of the computational domain.

Algorithm 1. After dividing the initial calculation area into parts in two coordinate directions, each processor receives its calculated area, as shown in Fig. 6, while adjacent areas are overlapped by two layers of nodes in a direction perpendicular to the partition plane.

After each processor receives information for its part of the region, the residual vector and its uniform norm are calculated. Then each processor determines the maximum modulo element of the residual vector and passes its value to all remaining calculators. Now, to calculate the uniform norm of the discrepancy vector, it is sufficient to find the maximum element on each processor.

Consider a parallel algorithm for calculating the correction vector:

$$
\left(D+\omega_{m} R_{1}\right) D^{-1}\left(D+\omega_{m} R_{2}\right) w^{m}=r^{m},
$$

where $R_{1}$-the lower-triangular matrix, and $R_{2}$ - the upper-triangular matrix. To calculate the correction vector, two equations must be solved successively: $\left(D+\omega_{m} R_{1}\right) y^{m}=r^{m}$, $\left(D+\omega_{m} R_{2}\right) w^{m}=D y^{m}$.

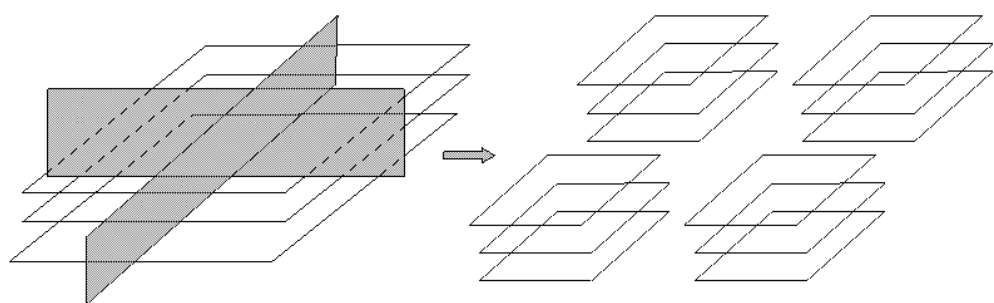

Fig. 6. Decomposition of the computational domain

First, the vector $y^{m}$ is calculated, and the calculation starts in the lower left corner. Then the calculation of the correction vector $w^{m}$ begins from the upper right corner. Fig. 7 shows the calculation of the vector $y^{m}$ (the transfer of elements is shown after the calculation of the two layers by the first processor).

In the first step of the calculation, the first processor processes the top layer. Then, overlapping elements are transferred to adjacent processors. In the next step, the first processor processes the second layer, and its neighbors - the first. Fig. 7 shows the transfer of the elements after the calculation of the two layers by the first processor. In the scheme for calculating the vector $y^{m}$, only the first processor does not require additional information and can independently process other parts of the region, the rest of the processors wait for the results from the previous processor until it passes the calculated values of the grid functions for the grid nodes located in the preceding positions of this line. The process continues until all layers are calculated. Similarly, a system of linear algebraic equations with an upper-triangular matrix can be solved to calculate the correction vector.

Then scalar products are calculated and the transition to the next iteration layer is performed. 


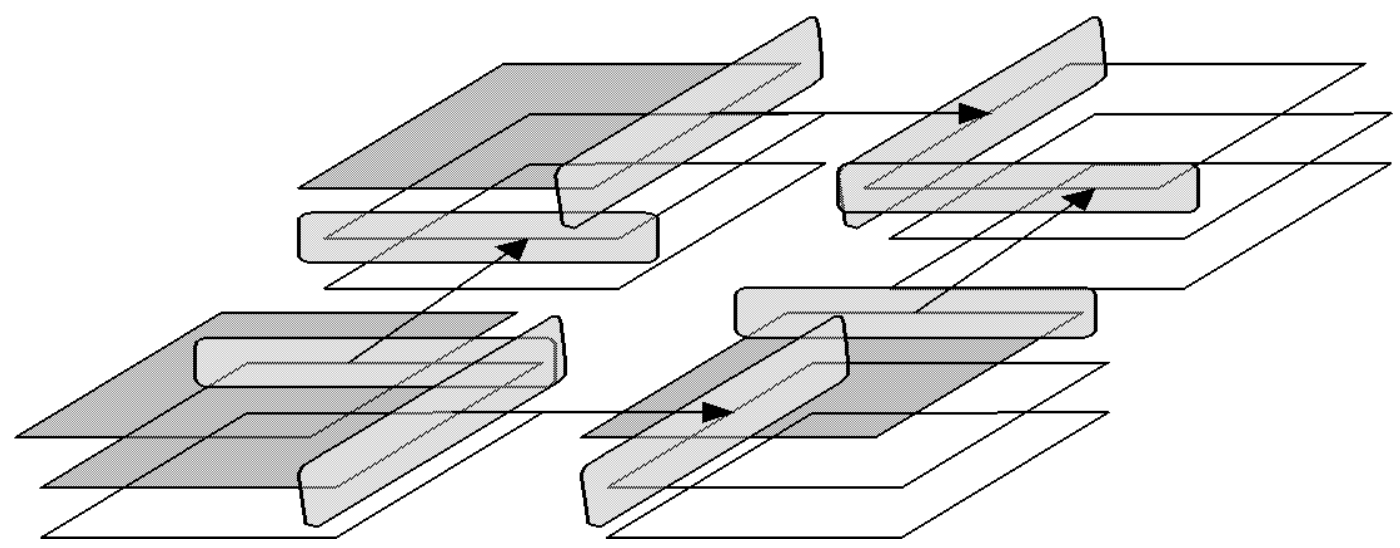

Fig. 7. The scheme for calculating the vector $y^{m}$

Let us construct a theoretical estimate of the time required to perform an MATM step for a system of linear algebraic equations with a seven-diagonal matrix by decomposition in two spatial directions on a cluster of distributed computations. The entire design area is distributed among the processors (total $\mathrm{n}$ processors $n=n_{x} \cdot n_{y}$ let $n_{x} \geq n_{y}$ ), i.e. each of them receives a region of the size $\frac{N}{n}, N=N_{x} N_{y} N_{z}$, where $N_{x}, N_{y}, N_{z}$ - the number of nodes in the spatial directions; $t_{0}$ - the time of execution of one arithmetic operation; $t_{x}$ - the response time (latency); $t_{n}$ - the time spent on transferring floating-point numbers.

Now we get theoretical estimates of the acceleration $S_{(1)}$ and efficiency $E_{(1)}$ of parallel algorithm 1:

$$
\begin{gathered}
S_{(1)}=\frac{n}{1+(\sqrt{n}-1)\left(\frac{36}{50 N_{z}}+\frac{4 n}{50 t_{0}}\left(t_{n}\left(\frac{1}{N_{x}}+\frac{1}{N_{y}}\right)+\frac{t_{x} \sqrt{n}}{N_{x} N_{y}}\right)\right)}, \\
E_{(1)}=\frac{S_{(1)}}{n}=\frac{1}{1+(\sqrt{n}-1)\left(\frac{36}{50 N_{z}}+\frac{4 n}{50 t_{0}}\left(t_{n}\left(\frac{1}{N_{x}}+\frac{1}{N_{y}}\right)+\frac{t_{x} \sqrt{n}}{N_{x} N_{y}}\right)\right)} .
\end{gathered}
$$

In theoretical estimates of acceleration, the case of a model problem with a rectangular region is considered. When solving a problem for a real reservoir, the design area has a complex shape. At the same time, the real acceleration is less than its theoretical estimate. The acceleration dependence obtained from the theoretical estimate can be used as an upper acceleration estimate for the parallel implementation of the MATM algorithm by decomposing the region in two spatial directions.

Algorithm 2. For the geometric partitioning of the computational domain for the purpose of uniform loading of the calculators (processors), the k-means method was used, based on minimization of the functional of the total sample variance of the scatter of elements (grid nodes) relative to the center of gravity of the subregions.

Let's describe the algorithm of k-means operation. 
1) The initial centers of the subdomains are selected using the maximin algorithm.

2) All calculated nodes are divided into $m$ cells according to the idea of Voronoi by the method of the nearest neighbor, i.e. the current design grid node $x \in X_{c}$, where $X_{c}$ - the subdomain, chosen from the condition $X_{c}$ where $s_{c}$ is the center of the region $X_{c}$.

3) New centers are calculated by the formula $s_{c}^{(k+1)}=\frac{1}{\left|X_{i}^{(k)}\right|} \sum_{x \in X_{i}^{(k)}} x$.

4) The stop condition $s_{c}^{(k+1)}=s_{c}^{(k)}$ for all $k=1, \ldots, m$. If the stop condition is not satisfied, then the transition to point 2 of the algorithm is carried out.

Fig. 8 shows the result of the k-means operation for model two-dimensional and threedimensional regions (arrows indicate exchanges between sub-areas).

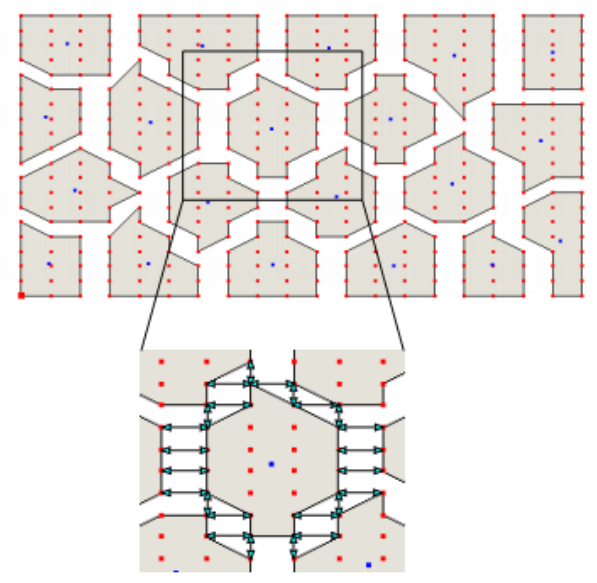

Fig. 8. Decomposition of the computational domain

Theoretical estimates of the acceleration and efficiency for Algorithm 2 were obtained analogously to the corresponding estimates of Algorithm 1:

$$
\begin{gathered}
S_{(2)}=\frac{n \cdot \chi}{1+(\sqrt{n}-1)\left(\frac{36}{50 N_{z}}+\frac{4 n}{50 t_{0}}\left(t_{n}\left(\frac{1}{N_{x}}+\frac{1}{N_{y}}\right)+\frac{t_{x} \sqrt{n}}{N_{x} N_{y}}\right)\right)} . \\
E_{(2)}=\frac{S_{(2)}}{n}=\frac{\chi}{1+(\sqrt{n}-1)\left(\frac{36}{50 N_{z}}+\frac{4 n}{50 t_{0}}\left(t_{n}\left(\frac{1}{N_{x}}+\frac{1}{N_{y}}\right)+\frac{t_{x} \sqrt{n}}{N_{x} N_{y}}\right)\right)},
\end{gathered}
$$

Where $\chi$ - the ratio of the number of calculated nodes to the total number of nodes (calculated and fictitious).

Parallel algorithms MATM were implemented on multiprocessor computer system SFedU. The work of the parallel algorithms 1 and 2 of the solution of the problem (1.1)-(1.3) was compared. The results are presented in the form of Table 2 , where $n-$ the number of processors; $t_{(k)}, S_{(k)}, E_{(k)}-$ 
operating time, acceleration and efficiency of the $k$-th algorithm; $S_{(k)}^{t}, E_{(k)}^{t}$ - theoretical estimates of the acceleration and efficiency of the $k$-th algorithm, $k=\{1,2\}$.

Table 2.

Comparison of acceleration and efficiency of algorithms

\begin{tabular}{|l|l|l|l|l|l|l|}
\hline$n$ & $t_{(1)}$ & $S_{(1)}^{t}$ & $S_{(1)}$ & $t_{(2)}$ & $E_{(2)}^{t}$ & $E_{(2)}$ \\
\hline 1 & 7,491 & 1,0 & 1,0 & 6,073 & 1,0 & 1,0 \\
\hline 2 & 4,152 & 1,654 & 1,804 & 3.121 & 1,181 & 1,946 \\
\hline 4 & 2,55 & 3,256 & 2,938 & 1,811 & 2,326 & 3,354 \\
\hline 8 & 1,45 & 6,318 & 5,165 & 0,997 & 4,513 & 6,093 \\
\hline 16 & 0,882 & 11,928 & 8,489 & 0,620 & 8,520 & 9,805 \\
\hline 32 & 0,458 & 21,482 & 16,352 & 0,317 & 15,344 & 19,147 \\
\hline 64 & 0,2656 & 35,955 & 28,184 & 0,184 & 25,682 & 33,018 \\
\hline 128 & 0,172 & 54,618 & 43,668 & 0,117 & 39,013 & 51,933 \\
\hline
\end{tabular}

From the data in Table 2, we can conclude that the algorithms developed on the basis of decomposition in two spatial directions and the k-means method can effectively be used to solve hydrodynamic problems for a sufficiently large number of computational nodes.

Using algorithm 2 on the basis of k-means to solve the bloom problem of the form (1.1)-(1.3) allows to increase the efficiency by $15 \%$.

3. Description of the program complex. To solve the problem (1.1)-(1.3), a set of applied programs «Azov3d» was created, allowing to calculate the fields of water flow rates, concentrations of pollutants, phytoplankton and zooplankton in areas of complex shape (Azov Sea and Taganrog Bay) on supercomputer. The software complex is designed for mathematical modeling of possible scenarios for the development of the ecological situation in coastal systems, using the example of the Azov-Black Sea basin, including a set of computational modules that allow: to take into account the factors influencing the distribution of pollutants in coastal systems (weather conditions, the influence of the coastline and the bottom relief); conduct a study of the dependence of pollutant concentrations, the degree and size of the affected zone of a water body on the intensity of the water flow, hydrophysical parameters, climatic and meteorological factors. Its features include high performance, reliability, as well as high accuracy of the resulting simulation results.

For mathematical modeling of hydrobiological and hydrodynamic processes in a threedimensional region of complex shape - the Sea of Azov and the Taganrog Bay, sequentially condensed rectangular meshes were used with the dimensions: $251 \times 351 \times 15,502 \times 702 \times 30$, $1004 \times 1404 \times 60, \ldots$.

Calibration and verification of the developed model for the shallow water reservoir was carried out on the basis of ecological data on the Sea of Azov, obtained during research expeditions conducted by SFU scientists, beginning in 2000. During the studies of the Azov Sea water area, the following species and concentrations of the main polluting waters of the Sea of Azov were studied: spatial distribution of salinity and temperature; oxygen regime; species composition of phyto- and zooplankton; mechanisms of the emergence and development of freezers in the central-eastern part of the reservoir [18-19]. 
The software package includes: a control unit, oceanological and meteorological data bases, interface systems, input-output and visualization systems. The development of the software complex used high-level language $\mathrm{C}++$, as well as MPI technology.

4. Results of numerical experiments. A number of numerical experiments were conducted to simulate the processes of «bloom» of waters in the Azov Sea for the period from April 1 to October 31, 2013. Fig. 9 shows the results of a numerical experiment for the reconstruction of the overseas phenomenon caused by the «bloom» of phytoplankton in July 2013.

A comparison was made between the work of the developed software package (PC) that implements the developed scenarios for the development of the ecological situation in the Sea of Azov using the numerical implementation of model problems of biological kinetics for plankton with similar work in the mathematical modeling of hydrobiological processes [20-23]. Analyzing the data of the SRC «Planet», presented in fig. $10 \mathrm{~A}$ (phytoplankton spots are visible, revealing the structure of currents), comparing with figure $10 \mathrm{~B}$, which presents the results of the distribution of phytoplankton concentrations for a 1 month time interval (July 2013), the initial distribution of current fields with the north wind, we note the qualitative correspondence of the results of phytoplankton simulation to the satellite image.
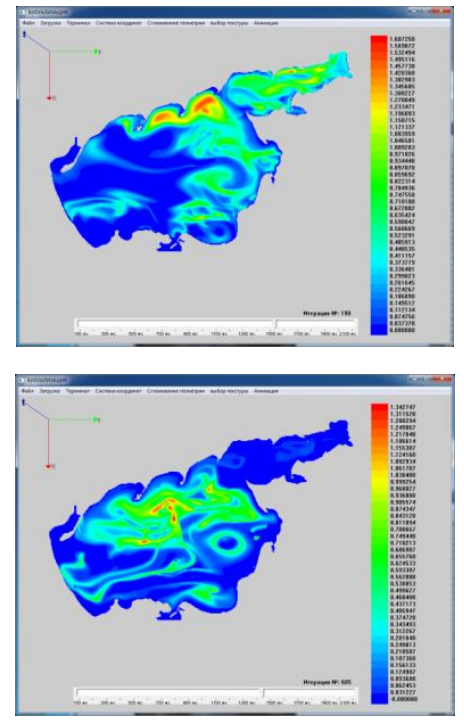
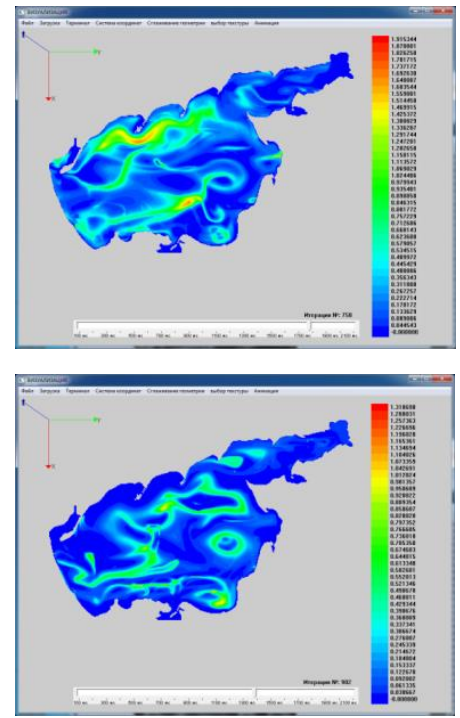

Fig. 9. Changes in the concentration of phytoplankton in the Azov Sea

The criterion for checking the adequacy of the constructed model (1.1)-(1.3) was the estimation of the simulation error with simultaneous taking into account the actual data from the available measurements, which was calculated using the formula: $\delta=\sqrt{\sum_{k=1}^{n}\left(S_{k \text { nat }}-S_{k}\right)^{2}} / \sqrt{\sum_{k=1}^{n} S_{k \text { nat }}^{2}}$, where $S_{k \text { nat }}$ - the concentration value obtained by in-situ measurements; $S_{k \text { nat }}$ - the concentration value calculated using the model (1.1)-(1.3). The concentrations of pollutants and plankton calculated for different wind situations were taken into consideration if the relative error did not exceed $30 \%$. 


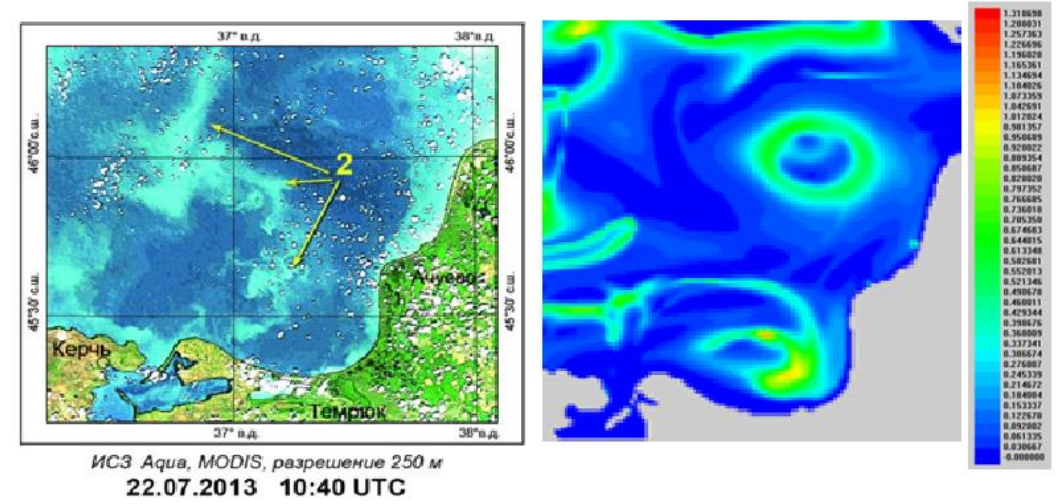

Fig. 10. A: satellite photo of the Azov Sea SIC «Planet»;

$\mathrm{B}$ : the result of PC operation (change in phytoplankton concentration)

Analysis of such PCs in shallow water bodies showed that as a result of its development it was possible to improve the accuracy of forecasts of changes in the concentrations of pollutants and plankton in a shallow water body by $10-15 \%$, depending on the model task of biological kinetics being solved.

Conclusion. The paper suggests a model of «bloom» of a shallow water body, used for the reconstruction of the fish's frozen fish, which occurred on July 16, 2013 in the southeastern part of the Azov Sea. A numerical implementation of the developed model on a multiprocessor computer system with distributed memory is performed. Theoretical calculations of the acceleration and efficiency of parallel algorithms are carried out. In the parallel implementation, the methods of decomposition of the grid regions for computationally laborious diffusion-convection problems, taking into account the architecture and parameters of the multiprocessor computer system, were used. The maximum acceleration was achieved at 128 computational nodes and was 43 times. Two algorithms were developed during the implementation of the parallel algorithm for solving the problem on multiprocessor computing system, for the distribution of data between processors, including an algorithm based on the k-means method, the use of which made it possible to increase the efficiency of the algorithm for solving the problem posed by $15 \%$ compared with the algorithm based on the standard partitioning of the calculation area. The use of a supercomputer has made it possible to shorten the time for solving the stated model problem, and to maintain the required accuracy of modeling the hydrobiological processes taking place in shallow water bodies, which is important in the problems of biological kinetics.

\section{References}

1. Sukhinov A.I., Chistyakov A.E., Semenyakina A.A., Nikitina A.V. Numerical modeling of the ecological condition of the Sea of Azov with the application of the schemes of the growing accuracy of the order on the multiprocessor computing system // Computer researches and modeling. 2016. T. 8, No. 1. pp. 151 - 168.

2. Sukhinov A.I., Chistyakov A.E., Nikitina A.V., Semenyakina A.A., Korovin I.; Schaefer G. Publications. Modeling of oil spill spread 2016 5th International Conference on Informatics, Electronics and Vision (ICIEV). 2016. pp: 1134 - 1139.

3. State Research Center «Planeta», http://planet.iitp.ru/english/index_eng.htm 
4. Sukhinov A.I., Nikitina A.V., Chistyakov A.E., Semenov I.S., Semenyakina A.A., Khachunts D.S. Mathematical modeling of eutrophication processes in shallow waters on the multiprocessor computer system / CEUR Workshop Proceedings. Vol. 1576. 2016. PP. 320-333,10th Annual International Scientific Conference on Parallel Computing Technologies, PCT 2016; Arkhangelsk; Russian Federation; 29 March 2016 through 31 March 2016; Code 121197.

5. Nikitina A. V., Sukhinov A.I., Ugolnitsky G.A., Usov A.B., Chistyakov A.E., Puchkin M.V., Semenov I.S. Optimal control of sustainable development in the biological recovery of the Azov Sea // Mathematical Models and Computer Simulations. 2017.9 (1), pp. 101-107.

6. Nikitina A.V., Tretyakova M.V. Modeling the process of algolization of a shallow water body by introducing into it a strain of green alga Chlorella vulgaris bin // Izvestiya SFU. Technical science. 2012. No. 1. pp. 128-133.

7. Sukhinov A.I., Nikitina A.V., Chistyakov A.E., Semenov I.S. Mathematical modeling of conditions of formation of freezes in shallow water reservoirs on a multiprocessor computer system // Computational methods and programming: new computing technologies. 2013. Vol.14. №1. pp. 103-112.

8. Sukhinov A.I., Chistyakov A.E., Protsenko E.A. Two-dimensional hydrodynamic model, taking into account the dynamic reconstruction of the bottom of a shallow water body // Izvestiya SFU. Technical science. 2011. № 8 (121). pp. 159-167.

9. Sukhinov A.I., Chistyakov A.E., Protsenko E.A. Construction of a discrete twodimensional mathematical model of sediment transport // Izvestiya SFU. Technical science. 2011. № 8 (121). pp. 32-44.

10. Sukhinov A.I., Chistyakov A.E., Protsenko E.A. Mathematical modeling of sediment transport in the coastal zone of shallow reservoirs. Mathematical models and computer simulations. 2014. Vol. 6. No. 4. pp. 351-363.

11. Samarsky A.A. The theory of difference schemes. Moscow: Nauka, 1989. 616 p.

12. Nikitina AV, Semenyakina AA, Chistyakov AE Parallel realization of the diffusionconvection problem on the basis of high accuracy schemes // Journal of Computer and Information Technologies. 2016, No. 7 (146). pp. 3-7.

13. Semenyakina A.A., Nikitina A.V., Chistyakov A.E., Sukhinov A.I. A complex of models, explicit regularized schemes of increased accuracy order and programs for predictive modeling of consequences of oil spills accident // Proceedings of the Conference «Parallel Computing Technologies: PCT-2016»/ 2016 pp. 308-317.

14. Sukhinov A.I., Chistyakov A.E., Semenyakina A.A., Nikitina A.V. Parallel implementation of the tasks of transport of substances and restoration of the bottom surface on the basis of schemes of increased accuracy order // Computational methods and programming: new computing technologies. 2015. Vol.16. pp. $256-267$.

15. Konovalov A.N. To the theory of alternating-triangular iteration method // Siberian Mathematical Journal. 2002. 43: 3. pp. 552-572.

16. Belotserkovsky O.M. Turbulence: New Approaches. Moscow: Nauka, 2003. 286 c.

17. Sukhinov A.I., Chistyakov A.E. Adaptive modified alternating-triangular iterative method for solving grid equations with a nonselfadjoint operator. // Mathematical Modeling. 2012. Vol. 24, №1. pp. 3-20. 
18. Nikitina A.V., Sukhinov A.I., Ugolnitsky G.A., Usov A.B., Chistyakov A.E., Puchkin M.V., Semenov I.S. Optimal management of sustainable development in the biological rehabilitation of the Azov Sea // Mathematical modeling. 2016. Vol. 28, №7. pp. 96 - 106.

19. Nikitina A.V., Puchkin M.V., Semenov I.S., Sukhinov A.I., Ugolnitsky G.A., Usov A.B., Chistyakov A.E. Differential-game model of prevention of freezing in shallow water bodies // Management of large systems. 2015. Issue 55. pp. 343 - 361.

20. Trân J.K. A predator-prey functional response incorporating an indirect interference and depletion // Verh. Internat. Verein. Limnol. 2008. Vol. 30, pp. 302 - 305.

21. Tyutyunov Yu., Senina I., Arditi R. Clustering due to acceleration in the response to the population gradient: a simple self-organization model // The American Naturalist. 2004, pp. 722-735.

22. Volterra V. Variations and fluctuations of the number of individuals in an animal species living together // Rapp. P. - V. Reun. Cons. Int. Explor. Mer. 1928. 3, pp. 3-51.

23. Yakushev E.V., Mikhailovsky G.E. Mathematical modeling of the influence of marine biota on the carbon dioxide ocean-atmosphere exchange in high latitudes // Air-Water Gas Transfer, Sel. Papers, Third Int. Symp., Heidelberg University, ed. by B. Jaehne and E.C. Monahan, AEON Verlag \& Studio, Hanau. 1995, pp. 37-48.

\section{Authors:}

Sukhinov Alexander Ivanovich, Vice Rector for Research and Innovative Activity, Don State Technical University (1st Gagarin Square, Rostov-on-Don, Russian Federation), Doctor of Science in Physics and Maths, Professor

Nikitina Alla Valerievna, Scientific Research Institute of Multiprocessor Computer Systems named after Academician Kalyaev Southern Federal University (2d Chekhov St., Taganrog, Russian Federation), Doctor of Technical Sciences, Associate professor

Chistyakov Alexander Evgenievich, Don State Technical University (1st Gagarin Square, Rostovon-Don, Russian Federation), Doctor of Science in Physics and Maths, Professor 
УДК 004.932:004.942

Использование многоканальных космических снимков для предсказательного моделирования процессов «цветения» фитопланктонных водорослей в мелководных водоемах на супер-ЭВМ*

\section{А.И. Сухинов, А.В. Никитина, А.Е. Чистяков ${ }^{* *}$}

Донской государственный технический университет, Ростов-на-Дону, Российская Федерация Южный федеральный университет, Ростов-на-Дону, Россия

Целью работы является разработка и исследование математической модели процессов «цветения» фитопланктонных водорослей, вызывающих заморные явления в мелководных водоёмах на основе современных информационных технологий и вычислительных методов. Для калибровки и верификации разработанной модели использовались экспедиционные данные и многоканальные космические снимки дистанционного зондирования Земли, полученные НИЦ «Планета». При параллельной реализации были использованы методы декомпозиции сеточных областей для вычислительно трудоемких задач, учитывающие архитектуру и параметры многопроцессорной вычислительной системы.

Ключевые слова: математическая модель, «цветение» фитопланктона, заморные явления, многоканальные космические снимки, супер-ЭВМ, параллельные алгоритмы

\section{Авторы:}

Сухинов Александр Иванович, проректор по НИР и инновационной деятельности, Донской государственный технический университет (344000 Ростов-на-Дону, пл. Гагарина, д. 1), доктор физико-математических наук, профессор

Никитина Алла Валерьевна, Научно-исследовательский институт многопроцессорных вычислительных систем имени академика А.В. Каляева Южного федерального университета (347928 Таганрог, ул. Чехова, д. 2), доктор технических наук, доцент

Чистяков Александр Евгеньевич, Донской государственный технический университет (344000 Ростов-на-Дону, пл. Гагарина, д. 1), доктор физико-математических наук, професор

\footnotetext{
* Работа выполнена при поддержке РНФ, проект N 17-11-01286.

** E-mail: E-mail: sukhinov@gmail.com, nikitina.vm@gmail.com, cheese_05@mail.ru.
} 